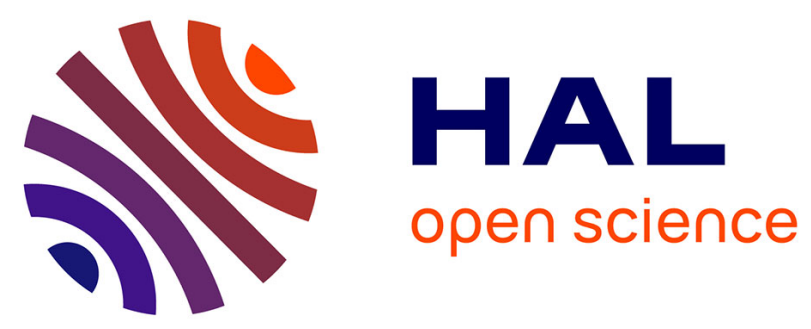

\title{
Longer schooling but not better off? A quasi-experimental study of the effect of compulsory schooling on biomarkers in France
}

Emilie Courtin, Vahe Nafilyan, Mauricio Avendano, Pierre Meneton, Lisa Berkman, Marcel Goldberg, Marie Zins, Jennifer B Dowd

\section{To cite this version:}

Emilie Courtin, Vahe Nafilyan, Mauricio Avendano, Pierre Meneton, Lisa Berkman, et al.. Longer schooling but not better off? A quasi-experimental study of the effect of compulsory schooling on biomarkers in France. Social science \& medicine, 2019, 220, pp.379-386. 10.1016/j.socscimed.2018.11.033 . hal-02967809

\section{HAL Id: hal-02967809 \\ https://hal.sorbonne-universite.fr/hal-02967809}

Submitted on 4 Nov 2020

HAL is a multi-disciplinary open access archive for the deposit and dissemination of scientific research documents, whether they are published or not. The documents may come from teaching and research institutions in France or abroad, or from public or private research centers.
L'archive ouverte pluridisciplinaire HAL, est destinée au dépôt et à la diffusion de documents scientifiques de niveau recherche, publiés ou non, émanant des établissements d'enseignement et de recherche français ou étrangers, des laboratoires publics ou privés. 


\title{
Longer schooling but not better off? A quasi-experimental study of the effect of compulsory schooling on biomarkers in France
}

\section{[Is compulsory education associated with biomarkers of health in mid-life? Evidence from a French quasi-experiment]}

\author{
Emilie Courtin, Vahe Nafilyan, Mauricio Avendano, Pierre Meneton ,Lisa F.Berkman \\ Marcel Goldberg, Marie Zins, Jennifer B.Dowd
}

\begin{abstract}
The strong association of educational attainment with health and mortality is well documented, but whether and how much of this association is causal remains less well understood. In this paper, we examine the impact of education on a range of biological markers representing cardiometabolic, immune, and liver and kidney health. We implemented a Regression Discontinuity Design (RDD) to assess the causal effect of a French compulsory schooling reform, which raised the minimum school leaving age from 14 to 16 for all children born after the $1^{\text {st }}$ of January 1953 on these biological markers of health in middle age. In conventional linear regression models, we find a clear educational gradient in biological risk, with respondents with secondary or tertiary education having significantly lower risk profiles than those who only have primary education. RDD analyses indicated that the reform increased average school leaving age by almost three months, with this increase exclusively driven by participants from blue collar families. Contrary to expectations, we found that eligibility for the reform was associated with higher levels of biological risk, particularly diastolic blood pressure and white cells count. These results are robust to sensitivity analyses and may suggest increased scrutiny of how policies to increase education impact health, and for whom.
\end{abstract}




\section{Introduction}

Despite overall gains in longevity, there remain persistent social gradients in chronic disease and premature mortality in many countries including those of the European Union (EU), where men with the lowest educational attainment have 4 times the mortality risk of those with the highest in the Czech Republic, Hungary and Lithuania, and around 2 times that of those with the most education in Sweden and Spain (Mackenbach et al., 2008). While a positive association between educational attainment and health is consistently reported in the literature, interpreting the causal impact of education on health has been more challenging, as both education and health in part are jointly determined by both early life characteristics (parental socioeconomic status, early life health) as well as underlying characteristics such as time preference and cognitive ability (Cutler \& Lleras-Muney, 2012).

Changes in compulsory schooling laws that obliged eligible cohorts to attend school longer have been used to assess the impact of additional years of schooling on a range of adult health outcomes (Banks \& Mazzona, 2012; Brunello, Fabbri, \& Fort, 2013; Clark \& Royer, 2013; Davies, Dickson, Davey Smoth, van den Berg, \& Windmeijer, 2018; Galama, Lleras-Muney, \& van Kippersluis, 2018; Glymour, Kawachi, Jencks, \& Berkman, 2008; Lager, Seblova, Flakstedt, \& Lovden, 2016; Nguyen et al., 2016; Schneeweis, Skirbekk, \& Winter-Ebmer, 2014). Previous studies have focused on disease endpoints, but the potential biological mechanisms underlying these associations in later life are not known.

This paper assesses the effect of changes in compulsory school leaving age on markers of biological risk in middle age in France. Previous research examining this policy change in the French case found no significant effect of education on mortality (Albouy \& 
Lequien, 2009). However, given the age of the affected cohort (born around 1953), mortality may not yet be the most sensitive indicator of underlying health. Here we examine the effect of the schooling reform on a range of biological indicators reflecting current and future health risk including anthropometrics, blood glucose and lipids, blood pressure, as well as liver and kidney function. Biomarkers offer several advantages in investigating the impact of social factors and policy changes on health. First, biomarkers may be more sensitive to health changes earlier in life and reflect subclinical disease that has not yet manifested itself in other morbidity or mortality statistics. They can also shed light on the specific mechanisms through which social factors impact health outcomes, for example whether through cardiovascular or immune pathways (Crimmins \& Seeman, 2004). Biomarkers can also provide a more objective measurement relative to self-reported health measures that can suffer from reporting biases that are correlated with health and social status (Dowd \& Todd, 2011). For examination of the current education reform, biomarkers are also sensitive to both health behaviors (diet and exercise) and clinical treatment (blood pressure and lipid medication), which may reflect the changes in the use of health information and time preference that could be induced by additional schooling.

We utilize the Berthoin reform in France, which raised the minimum school leaving age from 14 to 16 years in 1959. All individuals born after the 1 st of January 1953 had to stay two years longer in school. Previous research has shown that the reform had no effect on earnings (Grenet, 2013b), thus any health impact would be net of a permanent income effect. While higher income is one important pathway through which education may impact health, other pathways such as better use of health information and and/or a change in discount rates towards delaying gratification have been posited (Cutler \& Lleras-Muney, 
2012). Given the targeted impact of the compulsory schooling "treatment" (affected cohorts very close to the reform time, and those who would have otherwise dropped out of school), large sample sizes are required to identify health effects of the reform. Partially due to this limitation, few datasets have been available to test the impact of reforms on biological markers. To our knowledge only one study has looked at the effect of a compulsory schooling law on biomarkers, finding no significant effect of UK compulsory schooling reform on the inflammatory markers fibrinogen and C-reactive protein in the UK (Jürges, Kruk, \& Reinhold, 2013). We expand on this literature by examining the impact of the French reform on a larger range of biomarkers of health. Based on a recent review of the heterogeneous effects of compulsory schooling laws on health (Galama et al., 2018), we hypothesize that children from low-income families stand to benefit more from the reform in terms of schooling and potentially in terms of health in the long run.

\section{Data and Methods}

\section{Study population}

Our primary dataset is the CONSTANCES cohort, a representative sample of French adults 18-69 launched in 2012, with the aim of collecting data on 200,000 individuals over a 5-year period (Zins et al., 2010). Participants were randomly selected to take part in the study and invited to a one-day clinical examination in one of the 22 Health Screening Centres run by the National Health Insurance Agency. At baseline, a range of comprehensive health assessments were carried out by health professionals, and participants were asked to complete questionnaires about their health and socioeconomic circumstances. At the time of this study, clinical data was available for 58,029 respondents. As detailed 
below, we restricted our analysis to participants born at most three years before or after the cut off for eligibility to the reform $\left(1^{\text {st }}\right.$ of January $\left.1953, N=18,915\right)$.

\section{Anthropometry, blood pressure and blood-based biomarkers}

Participants were invited to a health examination, where anthropometry, blood pressure and serum were collected. Quality control was in place to ensure that high quality physiological data was collected across the different sites, details of which have been previously described (Ruiz et al., 2016).

Weight, height as well as waist and hip circumference were measured by the clinical team for all respondents. Body mass index (BMI) was calculated as weight in kilograms divided by height in meters squared. Blood pressure measurements (systolic and diastolic blood pressure) were taken from each arm after a one-minute rest. Blood samples were taken from all participants, who were instructed to fast 12 hours prior to collection, which was carried out between 8 and $10 \mathrm{am}$. Blood sugar levels were assessed by fasting blood glucose and blood lipid levels by total cholesterol, high-density lipoproteins and triglycerides. Liver function was measured by gamma-glumamyltransferase (gamma GT) and alanine transaminase. Serum creatinine was used as an indicator of kidney function. Hematology measures included counts of white blood cells, haemoglobin, haematocrit and platelets. The biomarker data were screened for outliers and unreasonable values removed (Magnusson Hanson et al., 2017). In addition, BMI, triglycerides, glucose, creatinine, gamma GT, white blood cell count and platelet values were log-transformed and haematocrit data was squared to decrease skewness. The scores for each biomarker was standardized to allow comparisons across measures. 


\section{Sociodemographic characteristics}

We obtained sociodemographic information from the self-administered questionnaires. Educational attainment was categorized as primary, secondary and tertiary education. We classified respondent's and parental occupational status as blue collar (e.g. manual worker, child minder, office employee), intermediate (e.g. teachers, nurses, technicians) and white collar (e.g. executives, engineers, physicians). Marital status was defined as married, in a civil partnership, single, separated, divorced or widowed. Country of origin was categorized as France, French oversea territories, Europe, Northern Africa, Sub Saharan Africa, Asia and other. Monthly household income was recorded as less than 450 euros, 540 to less than 1000 euros, 1000 to less than 1500 euros, 15000 to less than 2100 euros, 2100 to less than 2800 euros, 2800 to less than 4200 euros and 4200 euros or more.

Constances only records education as the highest qualification held by the respondents. However, the Berthoin reform increased the minimum school leaving age from 14 to 16, but had little on qualification attainment (Grenet, 2013). To assess the magnitude of the treatment, i.e. the effect of the Berthoin reform on school leaving age, we used data from the French Labor Force Survey (LFS) collected between 2003 and 2012. The French LFS is a household survey representative of the French population living in private households conducted by the French National Statistical Institute, the INSEE. We used data on the age at which respondents left full-time education to document the impact of the reform on school leaving age. We included in our analytical sample respondents born within three years of the reform. Due to the longitudinal aspect of the survey, some individuals are interviewed multiple times (up to six times). Because of our analysis is cross-sectional, we 
keep only data from the first interview, so that we only have one observation per individual. Our analytical sample includes 72,133 individuals.

\section{Study design and statistical analyses}

Our analysis involved two strategies. In the first, we performed traditional multivariate linear regressions to explore the baseline observational associations between educational attainment and each individual biomarker. These models were adjusted for age, age squared, gender, country of origin, occupational status, marital status and household income.

Next, we analyzed the effect of the Berthoin reform on each biomarker. The 'exogenous' sharp increase in school leaving age induced by the reform at the cut-off of the $1^{\text {st }}$ of January 1953 allows us to investigate the causal relationship of education on the clinical profile of affected cohorts. To do so, we implemented a regression discontinuity approach (RDD) (Lee \& Lemieux, 2010; Moscoe, Bor, \& Barnighausen, 2015). Following the identification strategy of Albouy and Lequien (2009), we selected individuals born at most 3 years before or after the Berthoin reform (born between 1950 and 1955, N=18,915) and estimate the discontinuity in the average school leaving age induced by the institutional change by comparing cohorts born immediately before or after the reforms.

We conducted an intent-to-treat analysis and our main model was as follows:

$$
b_{i o}=\beta_{0}+\beta_{1} D_{i c}+f\left(R_{i c}\right)+\boldsymbol{x}_{i c t} \beta_{2}+u_{i c t}
$$

Where bio $_{\text {ict }}$ is the individual biomarker value for individual $\mathrm{i}$ from birth cohort $\mathrm{c}$ at time $\mathrm{t}$; $\mathrm{D}_{\mathrm{ic}}$ is a binary variable taking the value of 1 if an individual was born up to three years after 
the cut-off date (the treated group), and of 0 if the individual was born up to three years prior to the cut-off date (the control group); $\mathrm{R}_{\mathrm{ic}}$ is an individual's birth cohort, relative to the cut-off measured in month; and $\mathbf{x}_{\text {ict }}$ is a vector of individual characteristics: age, age squared, gender and month of birth.

Because the reform would only be expected to increase the educational attainment of the marginal group of respondents who would not otherwise have continued their schooling, we also tested whether the effects differed by parental SES during the respondents' adolescence to estimate the effect for these "compliers." To address the issue of multiple hypothesis testing by subgroups and biomarkers, we implemented a set of adjustment methods (Bonferroni-Holm, Sidak-Holm and Westfall-Young) using the wyoung command (Jones, Molitor, \& Reif, 2018). All analyses were conducted using Stata 14.

\section{Results}

Sample characteristics

Table 1 displays the sample characteristics, by eligibility status to the Berthoin reform. The treated and control groups are broadly similar in terms of pre-reform characteristics, including gender and father's occupational class during adolescence. As the eligibility is based on the date of birth, respondents from the control group are older (63.67 on average) than the treated group (59.72 on average).

\section{Educational attainment and biomarkers}

Table 2 shows the OLS estimates for educational attainment and individual biomarkers. Higher education is consistently associated with healthier anthropometric and 
other biological measures in our sample. Both secondary and tertiary education were associated with lower BMI compared to primary education $(\beta=-0.167$ and $\beta=-0.333$ respectively, $p<0.001$, indicating a difference of 0.167 and 0.333 standard deviation). Respondents with tertiary education also had reduced hip circumference $(\beta=-0.175, p<0.01)$ and waist-hip ratio $(\beta=-0.266, p<0.001)$. Having tertiary education was also associated with lower diastolic blood pressure $(\beta=-0.161, p<0.01)$. Both secondary and tertiary educational levels were associated with lower levels of blood glucose and higher levels of HDL cholesterol, while only respondents with tertiary education had lower levels of triglycerides $(\beta=-0.211, p<0.001)$. No robust associations were noted between educational attainment and liver or kidney function measures. OLS results also suggest some education-related differences in white cells counts: respondents with tertiary education had lower levels of white cells compared to those with primary education $(\beta=-0.152, p<0.01)$.

\section{Compulsory schooling reform and biomarkers}

Next we examined the effect of eligibility to the Berthoin reform on biomarkers using the Regression Discontinuity Design analysis. Figure 1 shows the discontinuity in school leaving age for the cohorts born before and after the $1^{\text {st }}$ of January 1953 . The dotted line represents the cut-off for the first cohort affected by the reform. These results are confirmed in Table 3 which presents the association between the schooling reform and school leaving age. As anticipated, the impact of the educational reform was concentrated among those coming from blue collar families, the group most likely to otherwise have stopped schooling early prior to the reform. In this group, the reform increased the average time spent at school by 4.1 months. 
Table 4 displays the effect of being eligible for the reform on individual biomarkers. Eligibility for the reform was associated with BMI, waist circumference, waist-hip ratio, systolic and diastolic blood pressure, triglycerides, white cell count, and hematocrit among respondents from blue collar families, all in the direction of less healthy profiles for those eligible for the reform. After correction for multiple testing, eligibility for the reform remained associated with a significant increase in diastolic blood pressure $(\beta=0.153$, $p<0.001)$ and in white cells count $(\beta=0.146, p<0.001)$ among respondents from blue collar families. Notably, though in the opposite direction, the coefficient for diastolic blood pressure $(\beta=0.153)$ is roughly the same magnitude as the OLS estimate for tertiary vs. primary education $(\beta=-0.161)$. Figure 2 illustrates these results by presenting the nonparametric curves for these two outcomes by year of birth, among respondents from blue collar families. For both outcomes, there is an apparent discontinuity for the 1953 cohort, the first cohort affected by the policy. In supplementary analyses, we investigated whether the effect of eligibility to the reform differed by gender but no clear pattern emerged, although the effect tended to be stronger among men from blue collar families (see Appendix Tables 1 and 2).

\section{Sensitivity analyses}

The validity of the RDD rests on four key assumptions. (Smith, Levesque, Kaufman, \& Strumpf, 2016; Venkataramani, Bor, \& Jena, 2016). First, we have showed in Figure 1 and Table 2 that there is a clear discontinuity in the probability of exposure at the cut-off: children who were born after the $1^{\text {st }}$ of January 1953 stayed longer at school than their counterparts who were born before that date. Second, it is unlikely that individuals could manipulate assignment to the reform as the policy retrospectively targeted children who were 
aged six in 1959. Third, descriptive results presented in Table 1 show that the exposure groups are exchangeable around the cut-off in terms of pre-treatment variables such as parental SES during adolescence or parental country of origin. Fourth, the outcome probability should be continuous at the cut-off for eligibility in the absence of the reform. To confirm that our estimates are driven by the policy change and not by secular trends, we estimated the effect of 'placebo reforms', i.e. estimates for years in which the reform did not take place. Figure 3 displays the results for the cohorts born between 1947 and 1967. The effect of the compulsory schooling was consistent for diastolic blood pressure and white cells count while there was no evidence of discontinuities for most other cohorts. Our RDD results are also robust to different bandwidth sizes for the cohorts considered around the cut-off (Figure 4).

\section{Discussion}

Previous research suggests that educational attainment is associated with a range of health outcomes in adulthood. In this paper, we exploited a reform implemented in 1959 in France to estimate the effect of extending compulsory schooling age from 14 to 16 on biological health decades later, comparing these to traditional OLS regression results. Our findings indicate that in line with previous research, there is a clear association between higher education levels and lower biological risk evident in our sample across a variety of measures. However, we find that the impact of an educational policy which increased the number of years of schooling of children had if anything, negative effects on the biological markers measured, and these impacts were concentrated only among respondents who came from a blue-collar background. While these results may be surprising, they are consistent with other results from this cohort which found higher depression scores for women eligible 
for the reform (Courtin, et al, under review), as well as results from Sweden (Lager et al., 2016), Turkey (Dursun \& Cesur, 2016) and England (V. Nafilyan, Avendano, \& De Coulon, 2017) which question the premise that more education is invariably good for health. Elevated blood pressure is one of the most important risk factors for cardiovascular disease (Ettehad et al., 2016), and is sensitive to both health behaviors and acute and chronic stress (Gilbert-Ouimet, Trudel, Brisson, Milot, \& Vézina, 2014; Theodore et al., 2015). White blood count (WBC) is considered a marker of inflammation and immune function that is also associated with depressive symptoms and chronic stress (Beydoun et al., 2016). Elevation of these biomarkers for those eligible for the reform may thus be consistent with psychosocial or mental health pathways through which the reform was detrimental to health, although other behavioral pathways cannot be ruled out.

A first explanation for the negative health impacts of the reform might come from the absence of effects of the reform on education and labour market outcomes (Grenet, 2013a). Education is hypothesized to influence health partly by enhancing access to healthpromoting resources such as knowledge, social networks and better jobs and earnings. Evidence suggests that the reform did not lead to substantive improvements in these social and economic outcomes (Grenet, 2013a). Supplementary analyses in our sample confirm this pattern and suggest that longer schooling did not translate into higher educational attainment or better wages (Supplementary Table 3), suggesting that those who were forced to remain longer at school may not have benefitted economically from these additional years of schooling in the long run. Our findings on the effect of the reform on school leaving age suggest that children from blue collar families would have left school earlier, had it not been mandatory to continue until the age of 16. Thus for children from disadvantaged 
background, additional schooling instead of work might be detrimental for health when schooling is not associated with improved socio-economic outcomes.

In their recent paper, Galama, et al (2018), develop a theoretical framework of the relationships between human capital, schooling, mortality, and health behaviors, which allows for such dynamics whereby some children experience rather low returns and high costs to staying in school, potentially leading to negative outcomes of compulsory schooling laws. They show that a critical pathway through which education can affect health is skill formation; and that additional time spent in school following the compulsory schooling reform does not necessarily lead to additional skills. The Berthoin reform was not accompanied by a broader transformation of the educational system and did not change the larger educational distribution (Defresne \& Krop, 2016). Our findings are not consistent with resource substitution theory, which posits that the positive effects of education are stronger for groups from low SES backgrounds because they are more dependent on education in the absence of other health-promoting resources (Heckman, Moon, Pinto, Savelyev, \& Yavitz, 2010). The results from our stratified analyses shows that the Berthoin reform increases the number of years of schooling exclusively among children from blue collar families, which in theory would have then benefited the most from those additional years of education. The negative effects of the reform might suggest that factors associated with degree attainment or skill formation, which were absent here, are more important than the amount of time spent in school itself. This may lend indirect support to the 'sheepskin effect', the idea that respondents with credentials may have better health than those who did not receive degrees for the same number of years of schooling (Liu et al., 2014). This sheepskin effect is in line with previous studies conducted in the US context, which showed that higher degrees were associated with lower systolic and diastolic blood pressure (Liu et 
al., 2011) and 10-year risk of coronary heart disease (Liu et al., 2014), independent of the number of years of schooling. Future research should investigate whether policy changes that targeted the broader educational distribution rather than the lowest end might have different effects on health outcomes outcomes (Etile \& Jones, 2011)

This study has strengths and limitations. A major strength of our study is the use of a quasi-experimental design in a large population-based cohort. The data also included a large number of anthropometric and blood-based biomarkers for a large sample, which is unusual for quasi-experimental designs. Our biological markers may be more sensitive to subclinical changes in health risk than traditional measures of chronic health conditions or mortality. Our RDD estimates should also be understood as the overall effect of prolonging compulsory schooling, which presumably primarily affected those who would have otherwise left school.. Although this is of substantive interest as we show that the policy targeted children from blue collar families, these estimates provide no information about other settings or other policies which also have the potential to raise education attainment (Deaton, 2010; Heckman \& Urzua, 2010). The Berthoin reform only affected children from disadvantaged families, for whom the minimum school age coincided with the end of their education. While the results from our OLS models are likely be biased upward, they point towards a stronger protective effect of tertiary education on biological risk compared to secondary education. This illustrates the potential of exploiting other policy changes that encourage skill formation at all levels of the educational distribution in future research.

Overall, our study contributes to the growing literature that utilizes quasiexperimental designs to estimate the impact of changes in education on health outcomes and is one of the first to estimate the impacts of such a reform on biological markers of health. We found no evidence of positive benefits of the reform on biomarkers of health, and some 
evidence of increases in biological risk for those eligible for the reform. In combination with other results suggesting potential negative impacts of compulsory schooling for mental health (Dursun \& Cesur, 2016; Lager et al., 2016; Vahé Nafilyan, 2017), these results raise the possibility of unintended consequences for policy reforms that compel individuals to do things which may not be optimal in their circumstances. 


\section{References}

Albouy, V., \& Lequien, L. (2009). Does compulsory education lower mortality? Journal of Health Economics, 28, 155-168.

Banks, J., \& Mazzona, F. (2012). The effect of education on old age cognitive abilities: evidence from a Regression Discontinuity Design. The Economic Journal, 122(560), 418-448.

Beydoun, M., Beydoun, H., Dore, G., Canas, J., Fanelli-Kuczmarski, M., Evans, M., \& Zonderman, A. (2016). White blood cell inflammatory markers are associated with depressive symptoms in a longitudinal study of urban adults. Translational psychiatry, 6(9), e895.

Brunello, G., Fabbri, D., \& Fort, M. (2013). The causal effect of education on body mass: Evidence from Europe. Journal of Labor Economics, 31(1), 195-223.

Clark, D., \& Roayer, H. (2013). The effect of education on adult mortality and health: evidence from Britain. The American Economic Review, 103(6), 2087-2120.

Crimmins, E. M., \& Seeman, T. E. (2004). Integrating Biology into the Study of Health Disparities. In (Vol. 30, pp. 89-107): Population Council.

Cutler, D. M., \& Lleras-Muney, A. (2012). Education and health: insights from international comparisons. Retrieved from

Davies, N. M., Dickson, M., Davey Smoth, G., van den Berg, G. J., \& Windmeijer, F. (2018). The causal effects of education on health outcomes in the UK Biobank. Nature Human Behaviour, 2, 117-125.

Deaton, A. (2010). Instruments, randomization and learning about development. Journal of Economic Literature, 48, 424-455.

Defresne, F., \& Krop, J. (2016). La massification scolaire sous la Ve république: Une mise en perspective des statistiques de l'Éducation nationale (1958-2014). . Retrieved from Paris:

Dowd, J. B., \& Todd, M. (2011). Does Self-reported Health Bias the Measurement of Health Inequalities in U.S. Adults? Evidence Using Anchoring Vignettes from the Health and Retirement Study. The Journals of Gerontology Series B: Psychological Sciences and Social Sciences. doi:10.1093/geronb/gbr050

Dursun, B., \& Cesur, R. (2016). Transforming lives: the impact of compulsory schooling on hope and happiness. Journal of Population Economics, 29(3), 911-956.

Etile, F., \& Jones, A. M. (2011). Schooling and smoking among the baby boomers - An evaluation of the impact of educational expansion in France. Journal of Health Economics, 30(4), 811-831. 
Ettehad, D., Emdin, C. A., Kiran, A., Anderson, S. G., Callender, T., Emberson, J., . . . Rahimi, K. (2016). Blood pressure lowering for prevention of cardiovascular disease and death: a systematic review and meta-analysis. The Lancet, 387(10022), 957-967.

Galama, T. J., Lleras-Muney, A., \& van Kippersluis, H. (2018). The Effect of Education on Health and Mortality: A Review of Experimental and Quasi-Experimental Evidence. Retrieved from

Gilbert-Ouimet, M., Trudel, X., Brisson, C., Milot, A., \& Vézina, M. (2014). Adverse effects of psychosocial work factors on blood pressure: systematic review of studies on demand-control-support and effort-reward imbalance models. Scandinavian journal of work, environment \& bealth, 109-132.

Glymour, M., Kawachi, I., Jencks, C. S., \& Berkman, L. F. (2008). Does childhood schooling affect old age memory and mental status? Using state schooling laws as natural experiments. Journal of Epidemiology \& Community Health, 62(6), 532-537.

Grenet, J. (2013a). Is extending compulsory schooling alone enough to raise earnings? Evidence from French and British compulsory schooling laws. Scandinavian Journal of Economics, 115(1), 176-210.

Grenet, J. (2013b). Is extending compulsory schooling alone enough to raise earnings? Evidence from French and British compulsory schooling lwas. Scandinavian Journal of Economics, 115(1), 176-210.

Heckman, J. J., Moon, S. H., Pinto, R., Savelyev, P. A., \& Yavitz, A. Q. (2010). Analyzing social experiments as implemented: a reexamination of the evidence from the highscope Perry preschool program. Quantitative Economics, 1(1), 1-46.

Heckman, J. J., \& Urzua, S. (2010). Comparing IV with structural models: What simple IV can and cannot identify. Journal of Econometrics, 156(1), 27-37.

Imbens, G. W., \& Angrist, J. D. (1994). Identification and estimation of local average treatment effects. Econometrica, 62(2), 467-475.

Jones, D., Molitor, D., \& Reif, J. (2018). What Do Workplace Wellness Programs Do? Evidence from the Illinois Workplace Wellness Study. National Bureau of Economic. Washington, DC.

Jürges, H., Kruk, E., \& Reinhold, S. (2013). The effect of compulsory schooling on healthevidence from biomarkers. Journal of population economics, 26(2), 645-672.

Lager, A., Seblova, D., Flakstedt, D., \& Lovden, M. (2016). Cognitive and emotional outcomes after prolonged education: a quasi-experiment on 320182 Swedish boys. International Journal of Epidemiology, online first, 1-9.

Lee, D. S., \& Lemieux, T. (2010). Regression Discontinuity Designs in economics. Journal of Economic Literature, 48, 281-355. 
Liu, S. Y., Buka, S. L., Kubzansky, L., Kawachi, I., Gilman, S. E., \& Loucks, E. B. (2014). Sheepskin effects of education in the 10-year Framingham risk of coronary heart disease. Social Science \& Medicine, 80(1), 31-36.

Liu, S. Y., Buka, S. L., Linkletter, C. D., Kawachi, I., Kubzansky, L., \& Loucks, E. B. (2011). The association between blood pressure and years of schooling versus educational credentials: test of the sheepskin effect. Annals of Epidemiology, 21(2), 128-138.

Mackenbach, J. P., Stirbu, I., Roskam, A.-J. R., Schaap, M. M., Menvielle, G., Leinsalu, M., \& Kunst, A. E. (2008). Socioeconomic inequalities in health in 22 European countries. The New England journal of medicine, 358(23), 2468.

Magnusson Hanson, L. L., Westerlund, H., Goldberg, M., Zins, M., Vahtera, J., Hulvej Rod, N., . . Kivimäki, M. (2017). Work stress, anthropometry, lung function, blood pressure, and blood-based biomarkers: a cross-sectional study of 43,593 French men and women. Scientific Reports, 7(1), 9282. doi:10.1038/s41598-017-07508-x

Moscoe, E., Bor, J., \& Barnighausen, T. (2015). Regression discontinuity designs are underutilised in medicine, epidemiology, and public health: a review of current and best practice. Journal of Clinical Epidemiology, 68, 132-143.

Nafilyan, V. (2017). Does more education always improve mental health? Evidence from a British compulsory schooling reform. Retrieved from

Nafilyan, V., Avendano, M., \& De Coulon, A. (2017). Does more education always improve mental health? Evidence from a British compulsory schooling reform. HEDG Working Paper series. University of York.

Nguyen, T. T., Tchetgen Tchetgen, E. J., Kawachi, I., Gilman, S. E., Walter, S., Liu, S. Y., . . . Glymour, M. M. (2016). Instrumental variable approaches to identifying the causal effect of educational attainment on dementia risk. Annals of Epidemiology, 26(1), 71-76.

Ruiz, F., Goldberg, M., Lemonnier, S., Ozguler, A., Boos, E., Brigand, A., . . Zins, M. (2016). High quality standards for a large-scale prospective population-based observational cohort: Constances. BMC Public Health, $16(1), 877$.

Schneeweis, N., Skirbekk, V., \& Winter-Ebmer, R. (2014). Does education improve cognitive performance four decades after school completion? Demography, 51(2), 619 643.

Smith, L. M., Levesque, L. E., Kaufman, J. S., \& Strumpf, E. C. (2016). Strategies for evaluating the assumptions of the regression discontinuity design: a case study using a human apillomavirus vaccination programme. International Journal of Epidemiology, 46(3), 939-949.

Theodore, R. F., Broadbent, J., Nagin, D., Ambler, A., Hogan, S., Ramrakha, S., . . Moffitt, T. E. (2015). Childhood to early-midlife systolic blood pressure trajectories: early-life predictors, effect modifiers, and adult cardiovascular outcomes. Hypertension, HYPERTENSIONAHA. 115.05831. 
Venkataramani, A., Bor, J., \& Jena, A. B. (2016). Regression Discontinuity Designs in healthcare research. British Medical Journal, 352.

Zins, M., Bonenfant, S., Carton, M., Coeuret-Pellicer, M., Guéguen, A., Gourmelen, J., . . . Goldberg, M. (2010). The CONSTANCES cohort: an open epidemiological laboratory. BMC Public Health, 10(1), 479. doi:10.1186/1471-2458-10-479 


\section{TABLES}

Table 1. Sample characteristics, by eligibility group

\begin{tabular}{lccc}
\hline \hline & Treated $(N=9,286)$ & Control $(N=9,629)$ & $P$ value \\
\cline { 2 - 4 } Mean Age (SD) & $59.72(1.64)$ & $63.67(1.65)$ & $>0.001$ \\
Female $(\%)$ & 51.98 & 51.24 & 0.31 \\
Father's occupational class & & & 0.41 \\
during adolescence (\%) & & & \\
$\quad$ Low & 15.49 & 14.87 & \\
$\quad$ Intermediate & 38.74 & 39 & \\
$\quad$ High & 45.78 & 46.13 & \\
Respondent's educational & & & \\
level (\%) & & 3.35 & \\
$\quad$ Primary & 3.24 & 53.94 & \\
Secondary & 53.98 & 42.71 & \\
$\quad$ Tertiary & 42.78 & & \\
Respondent's occupational & & 31.8 & \\
class at entry in the survey & & 57.83 & \\
$\quad$ White collar & 28.35 & 10.37 & \\
Intermediate & 60.38 & & \\
Blue collar & 11.27 & & \\
\hline \hline
\end{tabular}


Table 2. Association between educational attainment and anthropometry, blood pressure, glucose and lipids, liver and kidney functions and hematology

\begin{tabular}{|c|c|c|}
\hline & $\bar{B}$ & 95\% CI \\
\hline \multicolumn{3}{|l|}{ 1. Anthropometry } \\
\hline \multicolumn{3}{|l|}{$B M I$} \\
\hline Secondary Education (ref. primary education) & $-0.167 * * * \#$ & -0.029 to 0.077 \\
\hline Tertiary Education & $-0.333^{* * * \#}$ & \\
\hline \multicolumn{3}{|l|}{ Waist circumference } \\
\hline Secondary Education (ref. primary education) & -0.087 & -0.048 to 0.067 \\
\hline Tertiary Education & $-0.175^{* * \#}$ & \\
\hline $\begin{array}{l}\text { Waist-hip ratio } \\
\text { Secondary Education (ref. primary education) } \\
\text { Tertiary Education } \\
\text { 2. Blood pressure }\end{array}$ & $\begin{array}{c}-0.17 * * * \\
-0.266^{* * * \#}\end{array}$ & -0.073 to 0.044 \\
\hline \multicolumn{3}{|l|}{ Systolic blood pressure } \\
\hline Secondary Education (ref. primary education) & -0.031 & 0.016 to 0.124 \\
\hline Tertiary Education & $-0.168^{* *}$ & \\
\hline \multicolumn{3}{|l|}{ Diastolic blood pressure } \\
\hline Secondary Education (ref. primary education) & -0.064 & 0.018 to 0.126 \\
\hline Tertiary Education & $-0.161 * * \#$ & \\
\hline \multicolumn{3}{|l|}{ 3. Glucose and lipids } \\
\hline \multicolumn{3}{|l|}{ Blood glucose } \\
\hline Secondary Education (ref. primary education) & $-0.22 * * * \#$ & -0.004 to 0.098 \\
\hline Tertiary Education & $-0.319 * * * \#$ & \\
\hline \multicolumn{3}{|l|}{ Total cholesterol } \\
\hline Secondary Education (ref. primary education) & $0.136^{* *}$ & -0.018 to 0.081 \\
\hline Tertiary Education & 0.102 & \\
\hline \multicolumn{3}{|l|}{ Cholesterol HDL } \\
\hline Secondary Education (ref. primary education) & $0.249 * * * \#$ & -0.047 to 0.068 \\
\hline Tertiary Education & $0.289 * * * \#$ & \\
\hline \multicolumn{3}{|l|}{ Triglycerides } \\
\hline Secondary Education (ref. primary education) & $-0.132 * *$ & 0.006 to 0.098 \\
\hline Tertiary Education & $-0.211 * * * \#$ & \\
\hline \multicolumn{3}{|l|}{ 4. Liver function } \\
\hline $\begin{array}{l}\text { Gamma GT } \\
\text { Secondary Education (ref. primary education) }\end{array}$ & -0.026 & -0.067 to 0.054 \\
\hline Tertiary Education & $-0.167 * *$ & \\
\hline \multicolumn{3}{|l|}{ Transaminase } \\
\hline Secondary Education (ref. primary education) & 0.012 & -0.042 to 0.052 \\
\hline Tertiary Education & -0.094 & \\
\hline \multicolumn{3}{|l|}{ 5. Kidney function } \\
\hline \multicolumn{3}{|l|}{ Creatinine } \\
\hline Secondary Education (ref. primary education) & $0.098^{*}$ & -0.046 to 0.069 \\
\hline
\end{tabular}


Tertiary Education

6. Hematology

White cells

Secondary Education (ref. primary education)

Tertiary Education

Haemoglobin

Secondary Education (ref. primary education)

Tertiary Education

Haematocrit

Secondary Education (ref. primary education)

Tertiary Education

Platelet values

Secondary Education (ref. primary education)

Tertiary Education
0.114*

$-0.083$

-0.014 to 0.100

$-0.152 * * \#$

$-0.016$

-0.077 to 0.005

$-0.048$

$0.132^{* *}$

-0.037 to 0.0689

$0.132^{*}$

$-0.026$

-0.020 to 0.091

$-0.081$

Notes: All models control for gender, age, age squared, respondent's current occupation,

respondent's country of origin, marital status and household income. Standard errors are clustered at the individual level and reported in parentheses.

${ }^{*} p<0.05,{ }^{* *} p<0.01, * * * p<0.001$.

\# Remains significant after adjustment for multiple testing using Bonferroni-Holm, Sidak-Holm, and Westfall-Young corrections. 
Table 3. Effect of eligibility to the 1959 Berthoin reform on age school leaving age, by gender and parental SES

\begin{tabular}{lcc}
\hline \hline & $\boldsymbol{B}$ & $95 \% \mathrm{CI}$ \\
All respondents & $0.211^{* * *}$ & $(0.116-0.307)$ \\
Respondents from white collar families & -0.210 & $(-0.624-0.204)$ \\
Respondents from intermediate families & 0.133 & $(-0.0359-0.303)$ \\
Respondents from blue collar families & $0.325^{* * *}$ & $(0.204-0.447)$ \\
\hline \hline
\end{tabular}

Notes: All models control for age, age squared, month of birth, birth cohort relative to the cut-off point, interacted with the treatment. Standard errors clustered at the month of birth level in parentheses. Bandwidth fixed at 36 months. ${ }^{* *} \mathrm{p}<0.01$; *** $\mathrm{p}<0.001$. 
Table 4. Effect of eligibility to the 1959 Berthoin reform on anthropometry, blood pressure, glucose and lipids, liver and kidney functions and hematology, by parental SES during adolescence

\begin{tabular}{|c|c|c|c|c|c|c|c|c|}
\hline & & All & & hite collar & & ermediate & & e collar \\
\hline & B & $95 \% \mathrm{CI}$ & B & $95 \% \mathrm{CI}$ & B & $95 \% \mathrm{CI}$ & B & $95 \% \mathrm{CI}$ \\
\hline $\begin{array}{l}\text { 1. Anthropometry } \\
B M I\end{array}$ & & & & & & & & \\
\hline $\begin{array}{l}\text { Eligibility to the reform } \\
\text { Waist circumference }\end{array}$ & 0.024 & -0.029 to 0.077 & 0.104 & -0.038 to 0.247 & -0.031 & -0.117 to 0.054 & $0.084 *$ & 0.007 to 0.161 \\
\hline $\begin{array}{l}\text { Eligibility to the reform } \\
\text { Waist-hip ratio }\end{array}$ & 0.009 & -0.048 to 0.067 & 0.007 & -0.144 to 0.159 & -0.081 & -0.164 to 0.0009 & $0.113^{* *}$ & 0.029 to 0.196 \\
\hline Eligibility to the reform & -0.014 & -0.073 to 0.044 & -0.093 & -0.250 to 0.064 & -0.085 & -0.172 to 0.002 & $0.086^{*}$ & 0.005 to 0.166 \\
\hline 2. Blood pressure & & & & & & & & \\
\hline Systolic blood pressure & & & & & & & & \\
\hline $\begin{array}{l}\text { Eligibility to the reform } \\
\text { Diastolic blood pressure }\end{array}$ & 0.07 & 0.016 to 0.124 & 0.103 & -0.041 to 0.249 & -0.014 & -0.114 to 0.085 & $0.128 * *$ & 0.038 to 0.217 \\
\hline Eligibility to the reform & 0.072 & 0.018 to 0.126 & -0.03 & -0.158 to 0.097 & 0.005 & -0.098 to 0.109 & $0.153 * * * \#$ & 0.066 to 0.239 \\
\hline $\begin{array}{l}\text { 3. Glucose and lipids } \\
\text { Blood glucose }\end{array}$ & & & & & & & & \\
\hline $\begin{array}{l}\text { Eligibility to the reform } \\
\text { Total cholesterol }\end{array}$ & 0.047 & -0.004 to 0.098 & -0.016 & -0.173 to 0.141 & -0.052 & -0.172 to 0.068 & 0.092 & 0.011 to 0.173 \\
\hline $\begin{array}{l}\text { Eligibility to the reform } \\
\text { Cholesterol HDL }\end{array}$ & 0.031 & -0.018 to 0.081 & $0.189 *$ & 0.030 to 0.347 & 0.026 & -0.062 to 0.115 & 0.033 & -0.041 to 0.108 \\
\hline $\begin{array}{l}\text { Eligibility to the reform } \\
\text { Tryglicerides }\end{array}$ & 0.01 & -0.047 to 0.068 & 0.17 & 0.002 to 0.339 & 0.04 & -0.049 to 0.130 & -0.083 & -0.193 to 0.026 \\
\hline Eligibility to the reform & $0.052^{*}$ & 0.006 to 0.098 & 0.015 & -0.122 to 0.153 & 0.025 & -0.065 to 0.117 & $0.113^{* * *}$ & 0.044 to 0.181 \\
\hline
\end{tabular}

\section{Liver function}


Gamma GT

Eligibility to the reform

Transaminase

Eligibility to the reform

$-0.006$

-0.067 to 0.054

$-0.068$

-0.239 to 0.103

$-0.06$

-0.153 to 0.033

$0.005-0.042$ to 0.052

$-0.023$

-0.163 to 0.117

$-0.004$

-0.094 to 0.084

$-0.02$

-0.091 to 0.049

\section{Kidney function}

Creatinine

Eligibility to the reform

$0.011-0.046$ to 0.069

$-0.085$

-0.254 to 0.083

0.022

-0.068 to 0.113

0.043

-0.042 to 0.128

\section{Hematology}

White blood cells

Eligibility to the reform

Haemoglobin

Eligibility to the reform $\quad-0.036$

Haematocrit

Eligibility to the reform $\quad 0.015$

Platelet values

Eligibility to the reform $\quad 0.035$

-0.014 to 0.100
-0.077 to 0.005

$-0.003$

0.00001

-0.078 to 0.078

$0.146 * * * \#$

0.052 to 0.240

$-0.094$

-0.256 to $0.067 \quad-0.058$

-0.146 to 0.029

0.023

-0.058 to 0.106

Notes: All models control for age, age squared, gender, month of birth, birth cohort relative to the cut-off point, interacted with the treatment. Standard errors are clustered at the month of birth level. The bandwidth is fixed at 48 months.

$* p<0.05, * * p<0.01, * * * p<0.001$.

\# Remains significant after adjustment for multiple testing using Bonferroni-Holm, Sidak-Holm, and Westfall-Young corrections. 


\section{FIGURES}

Figure 1. Impact of eligibility to the 1959 Berthoin reform on school leaving age (birth cohorts 1946-1959)

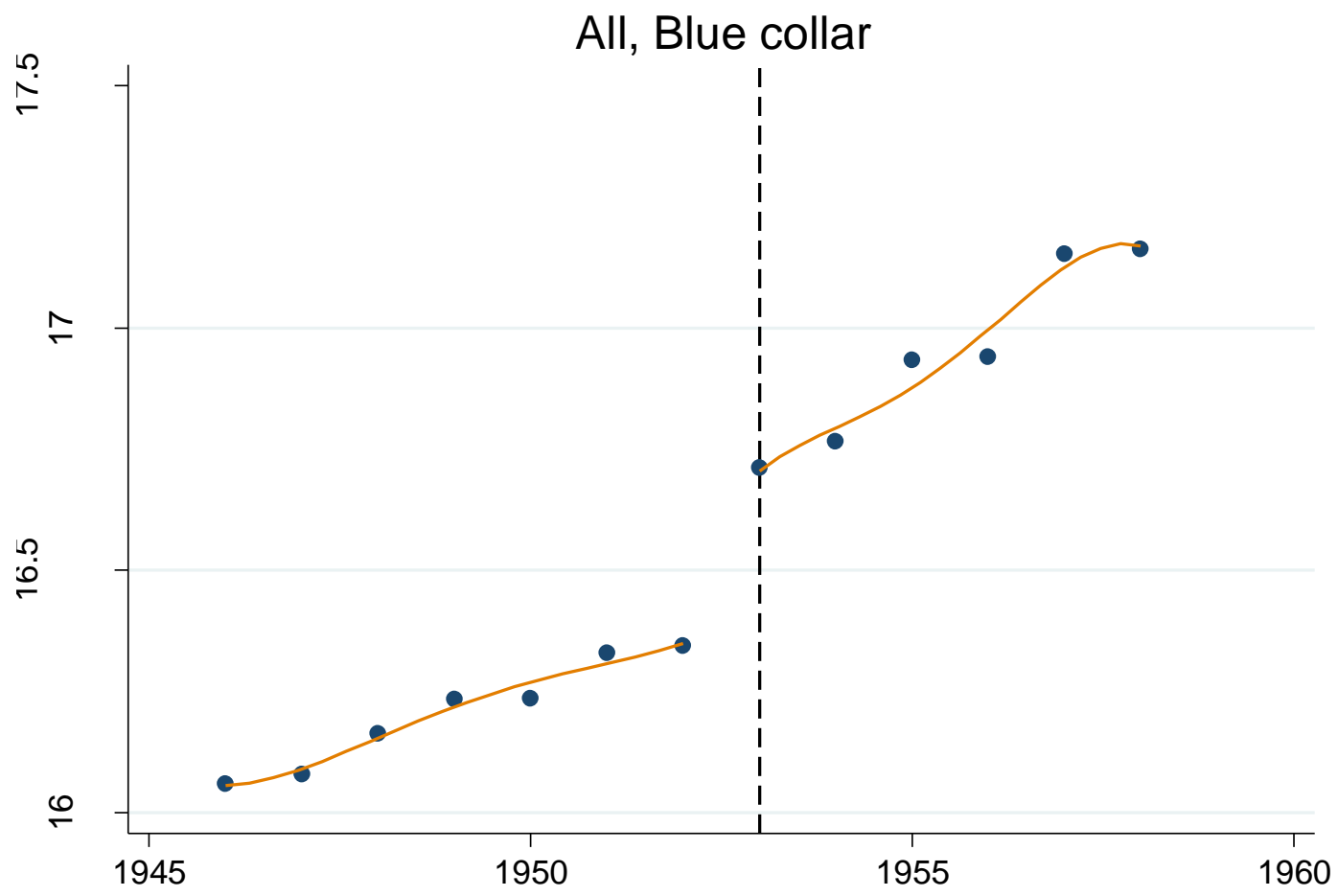

Notes: The dotted line represents the first cohort eligible to the reform (born after the $1^{\text {st }}$ of January 1953). 
Figure 2. Impact of eligibility to the 1959 Berthoin reform on diastolic blood pressure and white cells count (birth cohorts 1946-1959), respondents from blue collar families
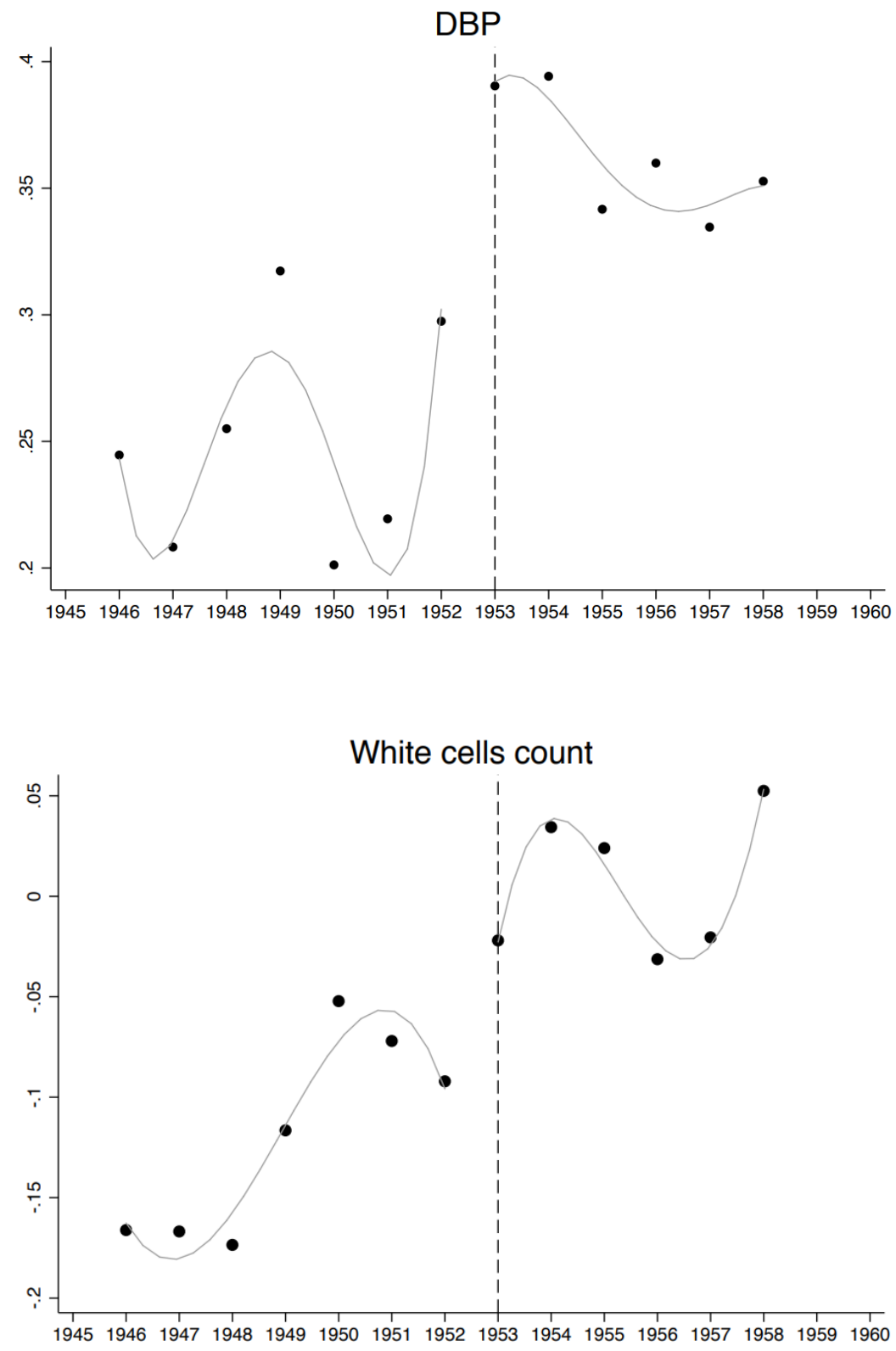

Notes: The dotted line represents the first cohort eligible to the reform (born after the $1^{\text {st }}$ of January 1953). 
Figure 3. Impact of the Berthoin and placebo reforms on diastolic blood pressure and white cells count (birth cohorts 1945-1967), respondents from blue collar families
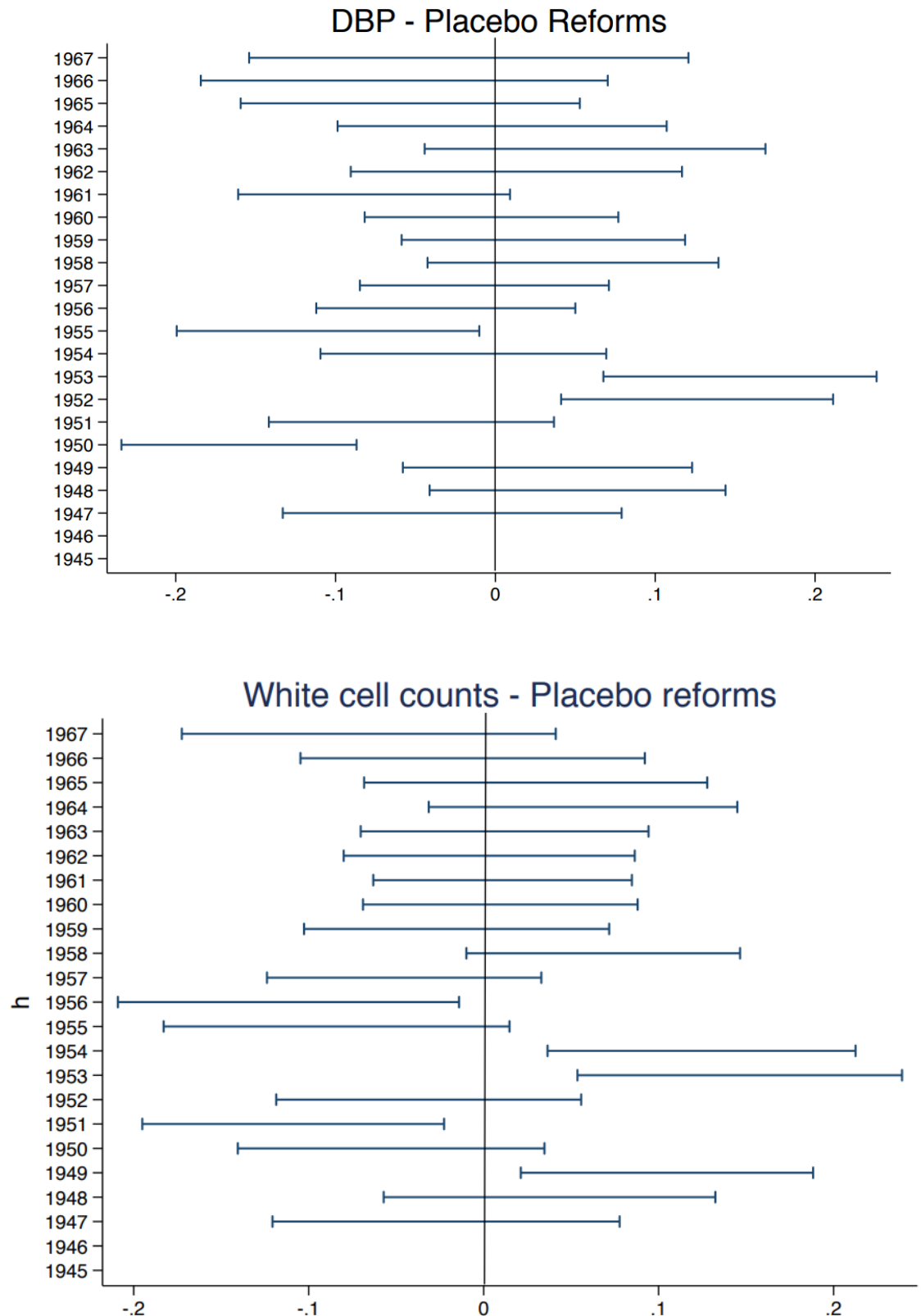
Figure 4. Effect of the variation in bandwidth size on the estimates (12 to 72 months around the cut-off)
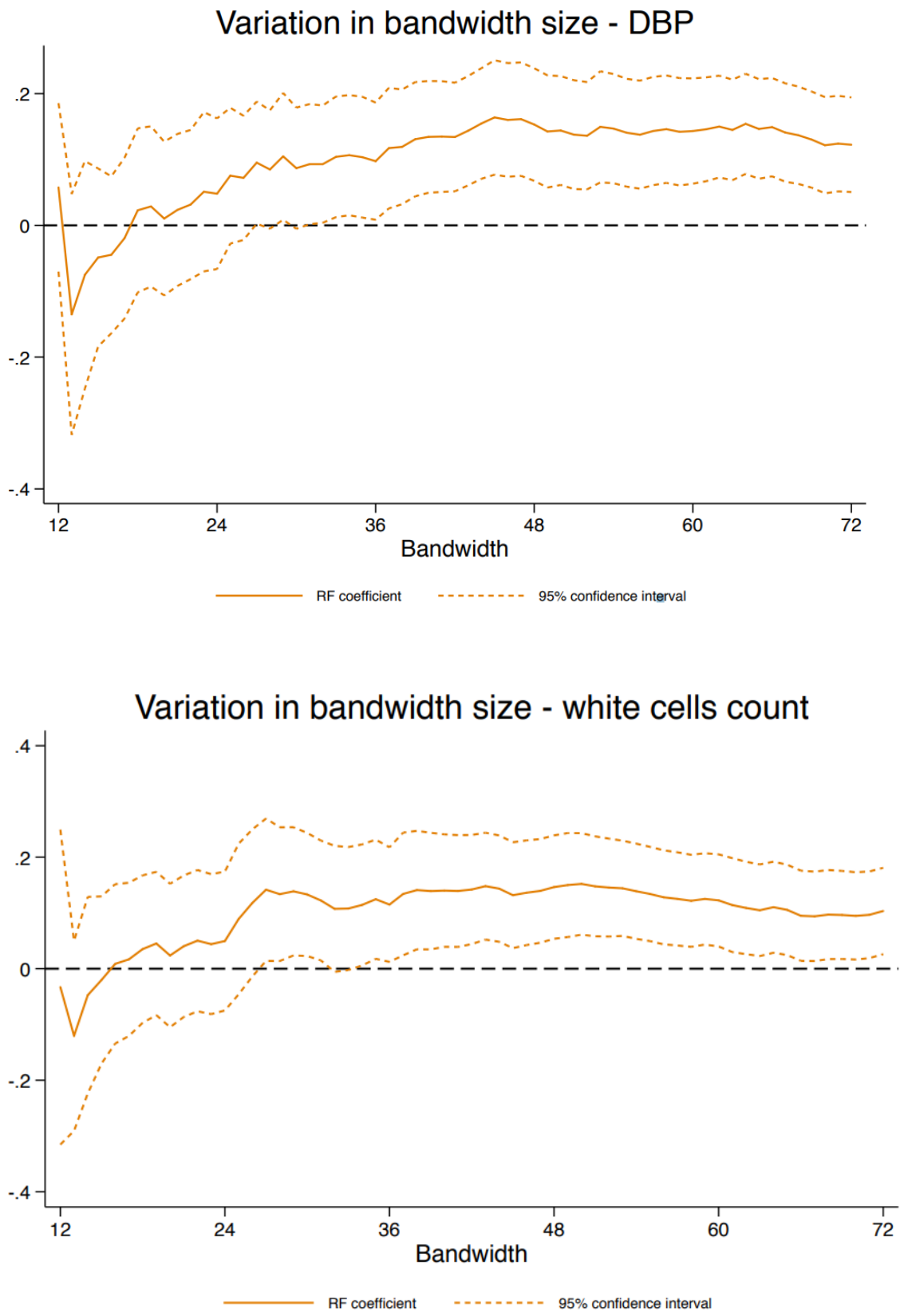


\section{SUPPLEMENTARY TABLES}

Appendix Table 1. Effect of eligibility to the 1959 Berthoin reform on biomarkers, males from blue collar families

\begin{tabular}{|c|c|c|}
\hline & B & $95 \% \mathrm{CI}$ \\
\hline \multicolumn{3}{|l|}{ 1. Anthropometry } \\
\hline \multicolumn{3}{|l|}{$B M I$} \\
\hline Eligibility to the reform & $0.103 *$ & 0.004 to 0.202 \\
\hline \multicolumn{3}{|l|}{ Waist circumference } \\
\hline Eligibility to the reform & 0.101 & -0.001 to 0.204 \\
\hline \multicolumn{3}{|l|}{ Waist-bip ratio } \\
\hline Eligibility to the reform & 0.065 & -0.016 to 0.146 \\
\hline \multicolumn{3}{|l|}{ 2. Blood pressure } \\
\hline \multicolumn{3}{|l|}{ Systolic blood pressure } \\
\hline Eligibility to the reform & 0.113 & -0.011 to 0.238 \\
\hline \multicolumn{3}{|l|}{ Diastolic blood pressure } \\
\hline Eligibility to the reform & $0.129 * *$ & 0.029 to 0.229 \\
\hline \multicolumn{3}{|l|}{ 3. Blood biochemistry } \\
\hline \multicolumn{3}{|l|}{ Blood glucose } \\
\hline Eligibility to the reform & 0.143 & 0.015 to 0.272 \\
\hline \multicolumn{3}{|l|}{ Total cholesterol } \\
\hline Eligibility to the reform & 0.038 & -0.071 to 0.148 \\
\hline \multicolumn{3}{|l|}{ Cholesterol HDL } \\
\hline Eligibility to the reform & 0.004 & -0.106 to 0.115 \\
\hline \multicolumn{3}{|l|}{ Triglycerides } \\
\hline Eligibility to the reform & $0.131 * * *$ & 0.036 to 0.225 \\
\hline \multicolumn{3}{|l|}{ 4. Liver function } \\
\hline \multicolumn{3}{|l|}{ Gamma GT } \\
\hline Eligibility to the reform & 0.016 & -0.111 to 0.144 \\
\hline \multicolumn{3}{|l|}{ Transaminase } \\
\hline Eligibility to the reform & -0.055 & -0.176 to 0.065 \\
\hline \multicolumn{3}{|l|}{ 5. Kidney function } \\
\hline \multicolumn{3}{|l|}{ Creatinine } \\
\hline Eligibility to the reform & 0.031 & -0.057 to 0.121 \\
\hline \multicolumn{3}{|l|}{ 6. Hematology } \\
\hline \multicolumn{3}{|l|}{ White blood cells } \\
\hline Eligibility to the reform & $0.173 *$ & 0.011 to 0.335 \\
\hline \multicolumn{3}{|l|}{ Haemoglobin } \\
\hline Eligibility to the reform & -0.074 & -0.168 to 0.019 \\
\hline Haematocrit & & \\
\hline
\end{tabular}


Eligibility to the reform $\quad 0.032-0.100$ to 0.165

Platelets

Eligibility to the reform $\quad 0.094 \quad-0.024$ to 0.212

Notes: All models control for age, age squared, month of birth, birth cohort relative to the cut-off point, interacted with the treatment. Standard errors are clustered at the month of birth level. The bandwidth is fixed at 48 months. ${ }^{*} p<0.05,{ }^{*} p<0.01,{ }^{* * *} p<0.001$. 
Appendix Table 2. Effect of eligibility to the 1959 Berthoin reform on biomarkers, females from blue collar families

B $95 \%$ CI

\section{Anthropometry}

$B M I$

Eligibility to the reform

0.052

-0.063 to 0.169

$W$ aist circumference

Eligibility to the reform

0.087

-0.016 to 0.192

Waist-hip ratio

Eligibility to the reform

0.054

-0.028 to 0.138

2. Blood pressure

Systolic blood pressure

Eligibility to the reform

0.132*

0.011 to 0.253

Diastolic blood pressure

Eligibility to the reform

$0.166^{* *}$

0.048 to 0.283

3. Blood biochemistry

Blood glucose

Eligibility to the reform

0.014

-0.097 to 0.126

Total cholesterol

Eligibility to the reform

0.056

-0.046 to 0.159

Cholesterol HDL

Eligibility to the reform

$-0.126$

-0.260 to 0.007

Triglycerides

Eligibility to the reform

0.085

-0.016 to 0.186

\section{Liver function}

Gamma GT

Eligibility to the reform

0.009

-0.108 to 0.127

Transaminase

Eligibility to the reform

$-0.011$

-0.107 to 0.085

\section{Kidney function}

Creatinine

Eligibility to the reform

0.001

-0.087 to 0.089

5. Blood biology

White cells

Eligibility to the reform

Haemoglobin

Eligibility to the reform

0.064

-0.011 to 0.141

Haematocrit

Eligibility to the reform

-0.150 to 0.107 
Platelets

Eligibility to the reform

0.09

-0.01 to 0.191

Notes: All models control for age, age squared, month of birth, birth cohort relative to the cut-off point, interacted with the treatment. Standard errors are clustered at the month of birth level. The bandwidth is fixed at 48 months. ${ }^{*} p<0.05,{ }^{*} p<<0.01,{ }^{* * *} p<0.001$. 
Supplementary Table 3. Effect of eligibility to the 1959 Berthoin reform on educational attainment and wages

\begin{tabular}{lcc}
\hline \hline & $\begin{array}{c}\text { High school diploma or } \\
\text { higher }\end{array}$ & Log of hourly wage \\
\cline { 2 - 3 } A. Gender & OR & $\beta$ \\
\cline { 2 - 3 } Men & 0.00772 & 0.0127 \\
Women & $(-0.0113-0.0268)$ & $(-0.00998-0.0355)$ \\
& 0.00220 & 0.00349 \\
B. Parental SES & $(-0.0174-0.0218)$ & $(-0.0266-0.0336)$ \\
White collar & & \\
& & -0.0106 \\
Intermediate & -0.0441 & $(-0.111-0.0901)$ \\
& $(-0.0884-0.000253)$ & 0.0262 \\
Blue collar & 0.000805 & $(-0.0112-0.0635)$ \\
& $(-0.0240-0.0256)$ & 0.00145 \\
\hline \hline
\end{tabular}

Sources: French Labour Force Survey (2003-2012)

Notes: All models control for age, age squared, month of birth, birth cohort relative to the cut-off point, interacted with the treatment. Standard errors clustered at the month of birth level. Bandwidth fixed at 48 months. ${ }^{* * *} p<0.001,{ }^{* *} p<0.01$. 